\title{
Sylvia Plath's The Bell Jar: a Mirror of American Fifties
}

\author{
Ghandeharion, A. ${ }^{1}$, Bozorgian, F. ${ }^{2}$, Sabbagh, M.R.G. ${ }^{3}$ \\ ${ }^{1,2,3}$ Ferdowsi University of Mashhad, Mashhad, IRAN \\ e-mails: ghandeharioon@um.ac.ir; azraghandeharion@gmail.com
}

\begin{abstract}
With its portrayal of a talented yet frustrated young American woman in the 1950s, Sylvia Plath's The Bell Jar (1963) depicts the experiences of a nineteen-year-old girl before her mental breakdown. Benefitting from a Friedanian second wave feminism, this paper aims to trace the root of disappointment and identity crisis in Plath's heroine, Esther Greenwood. It is understood that besides being a personal issue, her frustration is the outcome of sociocultural factors. The lack of role models and the contradictory messages sent by the media lead to her anxiety, disillusionment, and uncertainty. The Bell Jar proposes a solution: it is indeed possible for a woman to hold a fulfilling career and at the same time be a caring wife and a loving mother. And this is the answer Esther tries to figure out at a time when the boundaries between the domestic sphere and the outside world are clearly defined for women.
\end{abstract}

Keywords: Sylvia Plath; The Bell Jar; Betty Freidan; the America of the fifties.

\section{INTRODUCTION}

Sylvia Plath's The Bell Jar was first published in the UK in 1963 under the pseudonym Victoria Lucas. The novel received good reviews; it was critically acclaimed and became a best-seller. It was published again with Plath's name on the cover. At the time, this change attracted the attention of readers who felt the urge to read the work of a novelist, who was better known as a poet. Not just the different genre in her artistic creation, but also her recent suicide magnetized many readers and critics. Consequently, between 1966 and 1977, Plath's British publisher, Faber, sold over 140000 copies of the novel (cited in Gill, 2008, p. 74).

Critics have commented on the parallels between the events in the novel and Plath's real life. Plath herself underlines the confessional and semi-autobiographical nature of the novel when she calls it an "autobiographical apprenticework" (cited in Perloff, 1972, p. 507). Bawer adds to the weight of this claim by stating that in her journals, Plath feels as if she was stuck under the bell jar (in Bloom, Ed., 2007, p. 9). The events that take place in The Bell Jar mark a turning point in the heroine's worldview and her understanding of female identity. Esther gradually realizes that there is little room for her to flourish and appreciate her genuine self. Writing is her passion and she looks forward to a time when she can publish one of her own novels. Nevertheless, she becomes obsessed with her inadequacy and this results in a growing disappointment that hinders her progress. She believes she cannot rise to her full potentials since she is unfit for what the future has in store for her. In a Friedanian approach, this paper studies the sociocultural factors that lead to the central issue of the novel: the heroine's feelings of despondency and inadequacy.

\section{DISCUSSION}

\section{The Bell Jar and Mystique of the 1950s}

In 1963, Betty Friedan, known as one of the greatest feminist icons of the second wave feminism in America, wrote the groundbreaking book The Feminine Mystique in an attempt to explain the problem that many American women were facing in the fifties, namely, "the problem that has no name" (1974 [1963], p. 11). In her book, Friedan claims that American women are haunted by the feeling that something is wrong but their inability to explain the problem makes them even more restless (ibid.). This can be seen at the beginning of The Bell Jar, where Esther admits that "I knew there was something wrong with me that summer" (BJ", 1971 [1963], p. 1). Esther fails to give a clear description of that "something", which Friedan labels as "the problem that has no name".

\footnotetext{
* The Bell Jar
} 
In the first chapter of The Mystique, Friedan addresses women's dissatisfaction and frustration. She argues that women cannot explain the reason for their disappointment; they just know that something is wrong. Friedan regrets that many girls drop out of college to get married and start a family (p. 12). In her opinion, the rush for starting a family severely damages women's prospects. Friedan suggests that in this particular era passing college courses does not matter anymore since there seems to be a far more important exam for women to pass an exam that would help them get their most prestigious degree yet (ibid.). Friedan satirizes this new degree by referring to it as "Ph.T.", or "Putting the Husband Through" ( p. 12).

When Esther thinks about marriage, she cannot help but admit that

[i]t would mean getting up at seven and cooking [my husband] eggs and bacon and toast and coffee ..., and then when he came home after a lively, fascinating day he'd expect a big dinner, and I'd spend the evening washing up even more dirty plates till I fell into bed, utterly exhausted (BJ, p. 68).

Esther does not know if marriage can explain and define her life and she comes to this conclusion based on the women around her, the women whom she does not admire as good role models. Friedan challenges the ideology that being a wife or a mother defines a woman. This kind of social and cultural milieu promises limited prospects and this explains why in thinking about further options a woman is stupefied. Most of the girls that Friedan interviews admit that they are conditioned in a certain way; they are expected to go to college, perhaps hold a position in the outside world, meet a prince charming, and then get married right away "and that's as far as a girl has to think. After that, your husband determines and fills your life" (cited in Friedan, 1974 [1963], p.64).

Friedan notices that women are trapped in the popular Freudian belief that "anatomy is destiny" (p. 126). Esther, too, frowns at this biological essentialism which construes woman as an object of desire and a vehicle for procreation. In the scene where Esther accompanies Buddy Willard, a friend and a prospective husband, to a delivery room where a woman is in labor, she is appalled at the sight of the paraphernalia and the pregnant woman. She remarks that the woman is strapped to a "torture table" and that "[her] stomach stuck up so high I couldn't see her face or the upper part of her body at all" (BJ, p. 53).

This kind of description gives the impression that the baby is more important than the mother's identity. At that moment Esther cannot see anything beautiful about the scene, especially because the woman "seemed to have nothing but an enormous spider-fat stomach and two little ugly spindly legs" and during the birth "she never stopped making this unhuman whooing noise" (BJ, p. 53). These remarks on pregnancy and maternity remind us of Plath's "Metaphors" in which she compares a pregnant woman to "An elephant, a ponderous house,/ A melon strolling on two tendrils" (1981, p.116). The woman's body is thus defined by her pregnancy which gradually gets out of her control. Esther is not questioning motherhood; rather, she is giving herself the right to voice her doubts, displeasures, and even fears regarding things that for so long have remained unchallenged.

The America of the 1950s seems to be under the impression that childbirth is a miraculous event because woman, the symbol of birth and procreation, is reborn while giving birth to another human being. Therefore, it is generally believed that a woman has to be mentally deranged to not appreciate this blessing (Friedan 1974 [1963], p. 14, Ghandeharion and Feyz 2014). Friedan underlines the extremity of this popular belief which embellishes the "feminine fulfillment" by noting that "[i]n a New York hospital, a woman had a nervous breakdown when she found she could not breastfeed her baby" (p. 12). Buddy Willard, like Dr. Grantley Dick Read--the staunch advocate of natural childbirth--reinforces the clichés regarding motherhood and childbirth by claiming that once a woman has a baby, she would put all her future plans on hold in order to devote herself to her child. Esther remarks:

I also remembered Buddy Willard saying in a sinister knowing way, that after I had children I would feel differently, I wouldn't want to write poems any more. So I began to think maybe it was true than when you were married and had children it was like being brainwashed, and afterward you went about numb as a slave in some private, totalitarian state (BJ, p. 69).

Esther has the impression that men promote what they believe to be beneficial for everyone else. This patriarchal idea of woman as a birth-giving heroine is perpetuated as woman's self-image, an image that, according to Friedan, "ends in childbirth" (emphasis in the original p. 38). What Friedan and Plath's speaker are trying to suggest is that pregnancy and childbirth with all their hardships, though beautiful, have become a means to oppress and suppress the female and not to encourage the feminine. Therefore, marriage and having children, instead of becoming a means for the woman to nurture her true potentials 
and to blossom as a human being, have turned into a state in which she becomes trapped. This is done by men and women who disseminate the feminine mystique. The female as an equal to the male is thus ignored, and the feminine as an inferior to the masculine is emphasized.

Perloff (1972), too, insists that Esther and, by extension, Plath are not renouncing motherhood; rather, they are inviting us to see through the clichés by defamiliarizing the birth process (p. 516). In the birth scene, Esther is shocked at the woman's painful labor and describes the process "as if it were happening for the first time in history" (Perloff, ibid.). She observes that when the mother finally gives birth to the baby, she does not acknowledge that the baby is a boy, possibly because of the exhaustion, pain, and drugs. When Buddy tells Esther that the woman would forget the pain soon enough because she has been on painkillers the whole time, Esther thinks "a woman in terrible pain" might as well "go straight home and start another baby, because the drug would make her forget how bad the pain had been" (BJ, p. 53).

Interestingly, after Esther is hospitalized on account of her mental breakdown, her roommate is a woman called Mrs. Tomolillo, or so she thinks. The woman has the same name as the one who was in labor in the birth scene mentioned above. Esther might be delusional, especially given the state is in, and yet, this coincidence is significant. It might represent the striking nature of the birth scene and Esther's fears of childbirth. From this perspective, it could be said that at the back of her mind Esther thinks a pregnant woman is susceptible to mental breakdown, not only because of the excruciating pain, but also because of a loss of identity.

Esther wonders whether there is any other way of giving birth that is less painful but she does not venture to ask Buddy about it. She does not question this norm of society. She even imagines herself on the delivery table going under the same agonizing process just to see the baby full of life coming out of her body (BJ, p. 54). Friedan calls this "true feminine fulfillment" (p. 14) and maintains that this belief is developed in the fifties when society dictates the ultimate role of woman as a wife and a mother. According to this notion, being a mother and a wife is every woman's dream as it "fulfills" every aspect of their needs. The women who live according to this idea are women "whose greatest ambition has been marriage and children" (Friedan, p. 22). What is ironic about Esther is that she resists the stereotypical image of woman but at the same time, and not infrequently, considers the idea of becoming a housewife. Friedan believes that this ambivalence in girls results from a lack of role models who can offer them promising alternatives. Esther constantly worries when it comes to making her own decisions; she wants someone to choose for her because she is intimidated by the prospect of so many restrictive choices.

This indecisiveness is seen when Esther compares her life with a fig tree. This metaphor is the embodiment of her fears; she is in a quandary over her best course of action. She is dangling and will remain so unless she finds a way to reach for not one, but as many figs as she wants:

I saw my life branching out before me like [a] green fig tree[...]. From the tip of every branch[...]a wonderful future beckoned and winked. One fig was a husband and a happy home and children, and another fig was a famous poet and another fig was a brilliant professor, [...].I saw myself sitting in the crotch of this fig tree, starving to death just because I couldn't make up my mind which of the figs I would choose (BJ, pp. 62-63).

This comparison sheds light on the ambivalence in the narrator. Esther shows a distaste for what is conventionally expected of woman but at the same time she desires what she condemns. This might be because the heroine of The Bell Jar yearns for love and she thinks she can find it in being a wife, and better still, in motherhood (Ghasemi, 2004, p. 63). However, Esther does not want to make any compromises; she accepts these roles "as long as she could still speak from within her deeper self through her writing" (ibid.).

Throughout the novel, Esther is standing on the border between denying the norms altogether and accepting them compliantly. Furthermore, this shows that Esther is experiencing a "crisis in the unity of the self" (ibid). There are two sides at war with each other here: Esther's aspirations as an independent free woman, and her desire to be a wife and a mother. Esther is confused since she has been led to believe these are mutually exclusive choices.

Friedan elaborates on this stupefying uncertainty that a young woman is plagued. She claims that few girls are clear about their plans for the future. In her research, she finds out that most college girls do not like to be asked about their future plans; some of them even envy the married ones because those girls "who are going to get married right away are the lucky ones" (cited in Friedan, p. 63). 


\section{Esther and Role Models}

Esther's indecision results in her starvation as is elaborately explained by Smith (2010), who argues that "the feeding of young women" is one of the popular trends in the fifties (pp. 1-22). Smith focuses on eating moments in the novel to show how "behavioral models" (p. 4) try to feed Esther at the same time as they teach her the proper ways of eating. In other words, they give her a lesson in femininity.

What role models do girls have apart from their own mothers? And yet, these mothers cannot provide their girls with viable alternatives. Young women have to emulate their mothers who have gone to college, held a job for a short time, and once they were happily married, just gave up their dreams for the longwished-for security that a husband could provide. Esther's mother and Mrs. Willard are two significant role models whom Esther criticizes. She observes that "cook and clean and wash was just what Buddy Willard's mother did from morning till night, and she was the wife of a university professor and had been a private school teacher herself" ( $B J$, pp. 68-69).

The alternative to this life is spinsterhood or loneliness, an option that in itself is scary, since these girls do not want to be unpopular in the very society that has such reductive expectations. Those women who are labeled as 'old maid' are usually career women like doctors, writers, etc. This is clear when Esther is describing her feelings about Jay Cee, her boss. She is amazed at Jay Cee's ability because she is different from most of the women around her. Esther envies Jay Cee's determination; she believes that this woman is goal-oriented and is quite clear about what she wants and how she wants to achieve it. That is why she tells us "I wished I had a mother like Jay Cee. Then I'd know what to do. My own mother wasn't much help" (BJ, p. 32).

Esther likes Jay Cee because she does not completely fit the standard image of woman in the fifties. This partly explains her critique of conventional images: Jay Cee is unlike other fashion magazine bosses "with fake eyelashes and giddy jewelry"; her "brains", knowledge of "languages" and "quality writers" are more important than her "plug-ugly looks" (BJ, p. 5). Esther thinks Jay Cee does not fit in the stereotypical image of woman because she cannot imagine her out of "strict office suit and luncheon-duty hat and in bed with her fat husband" (ibid.). Such examples reveal Esther's anxiety about finding a role model. However, she is not very successful in finding one.

Friedan asserts that many women parade "their station wagons full of children" (p. 28) around because that is their idea of happiness. This reminds the reader of Esther's neighbor, Dodo Conway, who is about to have her seventh child, and for whom Esther has ambivalent feelings. She admits, "Dodo interested me in spite of myself" (p. 95). While the growing size of Dodo's family disgusts Esther, she marvels at how easily the other woman has found her place in the mainstream. That's why at times Esther wishes to "have a big cowy family, like Dodo Conway" ( $B J$, p. 108) partly because she thinks that can be the end of her struggles with womanhood.

Smith (2010) claims that such ambivalent feelings in women are caused by the American society at a time when the country has confusing notions of domesticity (p. 8). This is particularly reflected through advertisements and women's magazines. One such magazine is the Mademoiselle with which Plath is familiar especially because she has been its guesteditor for a short time. Plath's experience parallels Esther's editorship for Ladies' Day. The American woman of the fifties is faced with many baffling role models. However, these models either deliver contradictory messages or represent different variations of the same image.

Smith (2010) elaborates on the conflicting messages delivered by the media by stating that women have to be high-achievers at school or college without losing sight of gender-segregation in the domestic and public spheres. Thus, women are "encouraged to travel to Mexico" while, at the same time, they are "admonished to stay home and learn the best way to cook a chicken" (p. 6). Such "socially constructed guidelines for femininity" (p. 5) are incongruous with the demands expected of women.

The duality of the messages in the media breeds uncertainty, anxiety, and frustration. The dichotomy splits a woman's self-image: part of her wants to be a "happy housewife heroine" (Friedan, 1974 [1963], p. 28) while the other side of her wants to follow dreams of having a fruitful career. This can be seen in the first chapter of the novel where Esther is clearly disappointed in working for a women's magazine. She cannot admit it herself but we can see how this experience precipitates her mental breakdown. Esther's high credentials as a straight-A student are rewarded not with books and pencils but with smart clothes that are "hanging limp as fish in my closet" $(B J$, p. 1), clothes that she later feeds to the New York night. Gilbert (1978) has rightly referred to the incongruity between Esther's ambitions and her editorship for Ladies' Day as "the literary young woman's equivalent of being crowned Miss America" (p. 585). 


\section{The Postwar Culture and Madison Avenue}

The post-war culture is in part an explanation and a cause for the conflicting messages directed at women. The economic boom creates a comfortable and enjoyable consumerism, particularly for middle-class Americans, which can be seen in the hustle bustle of New York City and Madison Avenue. It is changing times. Americans are encouraged to simply enjoy life and the media makes a major contribution to this cause. Advertising agencies make it their priority to introduce aspects of American life in polished and appealing ways. Among these advertisements are images of happy families and young couples who snuggle next to each other, apparently satisfied with their lives. In such images one can see the ideal for the suburban housewife or "true feminine fulfillment" because this woman is "freed by science" from the "drudgery and dangers of childbirth" and her only concern is "her husband, her children, her home" (Friedan, p. 13).

In this atmosphere, if a woman feels unfulfilled, she has to find fault with herself and see wherefore such abnormal feelings are disturbing her. Esther suffers from the same dilemma once she faces the breathtaking grandeur and splendor of New York. Her attempt at being her true self is foiled by the standard image of woman that has been mildly and unobtrusively forced on her from all directions: her own mother, her friend Buddy Willard, his mother, and even Jay Cee. Esther comes to New York and is frustrated because "all the little successes I'd totted up so happily at college fizzled to nothing outside the slick marble and plate-glass fronts along Madison Avenue" (BJ, pp. 1-2).

With the technological developments in the fifties, practically nothing is left for a woman to do but to see herself in her house surrounded by an array of appliances and products to keep her healthy and strong. She will not miss the world outside. Friedan objects to this trend and argues that this image of woman is "young and frivolous, almost childlike; fluffy and feminine; passive; gaily content in a world of bedroom and kitchen, sex, babies, and home" (p. 30). Esther feels inadequate but she is not alone in that. The number of women who are feeling empty and incomplete is growing because they have failed to adjust to the feminine role and do not know how to envision a different life outside the domestic sphere. Before coming to New York, Esther is an uninitiated girl from "some out-of-the-way town" where she cannot even "afford a magazine" (BJ, 2). However, her one-month stay in New York marks a new phase in her life. She describes herself as a lucky girl with "patent leather shoes" holding a "black patent leather pocketbook to match", just like the ladies in the advertisements, and she has what "thousands of other college girls" in America yearn for (ibid.).

The first nine chapters of the novel cover Esther's onemonth stay in New York. During this time, the significance of fashion and advertisements is obvious since Esther describes the world around her in terms of advertisements. For instance, she observes that a young man has a "white toothpaste-ad smile" (BJ, p. 7) on his face, or when she orders a drink at the bar she remarks that "it looked clear and pure, just like the vodka ad" (BJ, p. 9). Esther's friend, Doreen, who is a sexy girl and takes much after the fifties sex icons like Marilyn Monroe, wears "full-length nylon and lace jobs you could half see through" (BJ, p. 4). The beauty editor of the magazine Esther works for in New York "persuaded Betsy [Esther's other friend] to cut her [blonde ponytail] and made a cover girl out of her" (BJ, p. 5). This shows the popular trend in America in which, according to Friedan, "three out of every ten women dyed their hair blonde" (p. 13).

These girls hang around the city since they wish to attract some promising man and settle down. This is more or less how young women were supposed to behave in the fifties. They would go to college and educate themselves but this would come second to getting married, especially since being married signifies social status, security, and happiness. Thus, staying single means being "emotionally incompetent" (Baker, 2007, p. 22).

Such a life of see-through dresses, blondes, matching pocketbooks, along with the need to secure the attention of an eligible bachelor has "marvelous, elaborate decadence" that attracts Esther "like a magnet" (BJ, p. 4). In the end, after a series of misfortunes and misadventures, Esther is about to leave New York; but she has unfinished business. In one of the key scenes of the novel, disillusioned Esther steps out on the parapet and throws away her expensive dresses one by one in the engulfing night.

Esther's disillusionment with the ideal image of woman in the fifties is linked to her editorship in Ladies' Day, a women's magazine that serves as a means to promote the desired model of womanhood. It is ironical that Esther wins the contest to be rewarded with one-month stay in the heart of one of the most successful agents of ideology, namely, the media. Esther has a chance to witness the strategies employed by women's magazine. She can see into the illusion "that the spotless hygiene of the fifties technicolor America is a facade which may conceal 
an unhealthy reality--it may even make you sick" (Kendell cited in Bloom, 2009, p. 28). This explains the significance of the poisoning discourse of New York. The unhealthy ideals are see-through and sickening.

\section{A Man's World}

The confusing nature of the messages in the fifties restricts women's choices while it makes allowances for men. For example, Esther's mother gives her an article called "In Defense of Chastity", written by a "woman lawyer" who strongly advises other women to keep their virginity until they get married because purity is only a woman's issue. The "woman lawyer", who represents social norms, claims that a man's world and emotions are different from a woman's and so men "wanted to be the ones to teach their wives about sex" (BJ, pp. 65-66).

Esther cannot bring herself to act upon this advice. She believes that it is both unfair and unreasonable that a man is allowed to lead a double life while a woman is advised to stay pure, naive, and uninitiated. Here, Esther takes issue with "the cult of virginity" (Valenti 2009, p. 17). Valenti asserts that "virginity is pretty much all about women" because "[n]o such definition exists for men or boys" (p. 21). This is another restrictive demand made by the society, and the nonconformist in Esther makes her bend the rules. She becomes obsessed with losing her virginity because "[e]ver since I'd learned about the corruption of Buddy Willard my virginity weighed like a millstone around my neck" (BJ, p. 186).

Buddy has lost his virginity to a waitress. $\mathrm{He}$ congratulates himself on this escapade since it proves his manhood, but Esther resents the freedom that is clearly a male prerogative. As the story goes on, we come to see that all the demands of this patriarchal society become like constraints that weigh Esther down; they become like a "millstone" that try to keep her in line. It seems that Esther is surrounded by men and women who keep reminding her that it is "a man's world" (Baker, 2007, p. 14). A metaphor that best describes this popular belief of the 1950s is the arrow metaphor used by Mrs. Willard. She tells her son, Buddy, who is kind enough to pass the remark to Esther, that "[w]hat a man is is an arrow into the future and what a woman is is the place the arrow shoots off from" (p. 58). The metaphor is supposed to tell Esther that her place is on the ground not in the sky where a man is free to fly like an "arrow". What this metaphor suggests is that "men must thrust into the future" (Friedan 1974 [1963], p. 71); woman is therefore pushed into the background as a person whose main aim is to help the man to "shoot off".
Sabbagh and Bozorgian (2015) discuss these type of metaphors in relation to Esther's strong desire for movement and her fear of inertia and confinement. They propose that Esther's objection to this metaphor stems from her "claustrophobia" and her yearning for a "dynamic life" (p. 119). These two features of the heroine's personality are behind comments such as "I wanted change and excitement and to shoot off in all directions myself, like the colored arrows from a Fourth of July rocket" (BJ, p. 68), or "[i]f neurotic is wanting two mutually exclusive things at one and the same time, then I'm neurotic as hell. I'll be flying back and forth between one mutually exclusive thing and another for the rest of my days" (BJ, p. 76). In her outrage, Esther emphasizes that she abhors being like "Mrs. Willard's kitchen mat" ( $B J$, p. 69), who, in Esther's eyes, is the epitome of servitude. The kinetic images that arise from Esther's above comments further establish her desire for "change and excitement" (BJ, p. 68) and her distaste for anything that brings a static life.

The arrow metaphor reminds one of John Donne's famous poem "A Valediction: Forbidding Mourning" (written in 1633) in which he places woman in the position of the fixed foot of a compass that would bend and turn in accordance with the movements of the other foot--the man: "If they be two, they are two so/ As stiff twin compasses are two;/ Thy soul, the fixed foot, makes no show/ To move, but doth, if th' other do (emphasis added, Donne LL 25-32, p. 1276). Here, as well as in the case of the arrow metaphor, the male speaker shapes his experiences about women through metaphors. Kittay observes that man regards himself as the norm against which woman is evaluated and defined. Therefore, woman is characterized as the other, an intermediary between "one stage of life and the next, between the familiar and the new, [...] to mediate man's conceptualizations between himself and those alterities he must encounter" (1997, p. 266). It goes without saying that such metaphorical references to women initiate the othering which is itself a vehicle to promote the feminine mystique. This explains why the novel's arrow metaphor is criticized by Esther. The arrow represents all the freedom that Esther longs for: the freedom to opt for "mutually exclusive things"; the freedom to lose her virginity without having to worry about an unwanted pregnancy; and finally, the freedom to transcend the boundaries set by her sociocultural milieu.

\section{CONCLUSION}

Esther is trying to reconcile two warring parts of her psyche. One part of her wants to get married and have kids, while the other aims as high as becoming a successful writer. She tries to prove to others that 
these two are not mutually exclusive or contraries; rather these two selves give a woman her ability to "shoot off in all directions". This is what being a woman means, but others do not think that Esther is capable of handling contraries at one and the same time.

The Bell Jar endeavors to show that there is no problem with leading a double life, in the positive sense of the term. Esther's quest throughout the novel suggests that being a wife and a mother are not at odds with being a writer. Writing is a career that could stand for all the productive and creative occupations that any woman can and should try. This duality in the nature of woman and, first and foremost, she is the one who should recognize it and respect it. Repressing this dual consciousness would not help; it will only trap the woman under a bell jar. Others must acknowledge the existence of these two sides and refrain from labeling it as "neurotic" or insane. Friedan claims the same: "Love and children and home are good, but they are not the whole world" because women should not "accept this picture of a half-life, instead of a sharing in the whole of human destiny" (p. 60).

This "half-life" is obviously incomplete until it is reconciled with the other half that is being an active participant in the world outside home. These two sides are not mutually exclusive. Rather, they are complementary; they cannot be separated since they give meaning to each other. Unless the two halves come together, the woman is incomplete, frustrated, and stifled. Plath does not force a clear resolution on the novel's ending. We are not sure whether Esther is "healed" the way her mother would expect. The ending instead encourages us to ask, "What was really the problem? What were Esther's family and the doctors trying to achieve? What needs to be healed?" Esther's mother, Buddy Willard and his family, and Doctor Gordon encourage her feminine self to prevail. However, Esther leaves, probably healed from the schism that has separated these two selves. This is how she confronts the dead end. She symbolically cements the crack between the two selves, and thus makes a unified whole. This is her secret in surviving the sour air under the bell jar: the acceptance of two "mutually exclusive" things.

\section{REFERENCES}

Baker, P. (2007). Fashions of a decade: The 1950s. New York: Infobase Publishing.

Bawer, B. (2007). Sylvia Plath and the poetry of confession. in H. Bloom (Ed.), Bloom's modern critical views: Sylvia Plath (pp.7-20). New York: Infobase Publishing.

Bloom, H. (Ed.). (2009). Bloom's guides: Sylvia Plath's The bell jar. New York: Infobase Publishing.

Donne, J. (1633). A valediction: Forbidding mourning. In M. H. Abrams et al (Eds.). The Norton Anthology of English Literature. Vol. 1. 8th ed. New York: W, W. Norton \& Company.

Friedan, B. (1974 [1963]). The feminine mystique. New York: Dell Publishing Co., INC.

Ghandeharion, A. \& Feyz, M. (2014). Desperate housewives in Albee's who's afraid of Virginia Woolf? Analele Universităţii Ovidius din Constanţa. Seria Filologie, 25(1), 12-21.

Ghasemi, P. (2004). Sylvia Plath's self-portrayal: The issue of double consciousness. Journal of the Faculty of Letters and Humanities. Shahid Bahonar University of Kerman, No. 14, 51-68. Noor Magazine. Stable URL: http://www. noormags.com/view/fa/articlepage/314624 accessed: April 22, 2014.

Gilbert, S. M. (1978). A fine, white flying myth: confessions of a Plath addict". The Massachusetts Review. 19(3), 585-603. JSTOR Stable URL: http://www.jstor.org/stable/25088890 accessed: Nov. 25, 2014

Gill, J. (2008). The Cambridge introduction to Sylvia Plath. Cambridge: Cambridge University Press.

Kittay, E. F. (1997). Woman as Metaphor. In D. Tietjens Meyers (Ed.), Feminist social thought: A reader (265-285). New York: Routledge.

Perloff, M. G. (1972). A ritual for being born twice: Sylvia Plath's the bell jar. Contemporary Literature. University of Wisconsin Press, 13(4), 507-522. Stable URL: http://www.jstor. org/stable/1207445

Plath, S. (1971 [1963]). The bell jar. New York: Bantam Books, Published by Arrangement with Harper \& Row, Publishers.

Smith, C. J. (2010). The feeding of young women: Sylvia Plath's the bell jar, mademoiselle magazine, and the domestic ideal. College Literature. 37(4)., 1-22. JSTOR Stable URL: http://www.jstor.org/stable/27917762 Accessed: 09/05/2014

Valenti, J. (2009). The purity myth: How America's obsession with virginity is hurting young women. Berkeley: Seal Press.

Sabbagh, M. R. G., \& Bozorgian, F. (2015). The bell jar: A study in characterization, figure, and ground. In 2nd Conference on Interdisciplinary Approaches to Language Teaching, Literature and Translation Studies, 113-122. 